\title{
Functional morphology of burrows and trophic modes of three thalassinidean shrimp species, and a new approach to the classification of thalassinidean burrow morphology
}

\author{
Lois A. Nickell ${ }^{1, *}$, R. James A. Atkinson ${ }^{2}$ \\ ${ }^{1}$ Dunstafinage Marine Laboratory, PO Box 3, Oban, Argyll, Scotland PA34 4AD, UK \\ ${ }^{2}$ University Marine Biological Station, Millport, Isle of Cumbrae, Scotland KA28 OEG, UK
}

\begin{abstract}
The burrow morphology and feeding behaviour of 3 species of thalassinidean shrimps, Callianassa subterranea, Jaxea nocturna and Upogebia stellata, from organically enriched sediments on the west coast of Scotland were studied using a resin casting technique and from observations in situ and in the laboratory. C. subterranea is primarily a sub-surface deposit feeder but can also supplement its diet by suspension feeding. The burrow consists of a lattice of tunnels and chambers connected to the surface by an inhalant and exhalant shaft and can reach depths of greater than $86 \mathrm{~cm}$. J. nocturna is also a deposit feeder but uses a resuspension technique. Sub-surface material is taken but this species may also scavenge organic material from the sediment surface. The burrow is relatively persistent with a wide spiralling shape. Burrow depths in excess of $92 \mathrm{~cm}$ have been recorded. U. stellata is primarily a suspension feeder but has the ability to deposit and resuspension feed. Burrows comprise several connected $\mathrm{U}$ - and Y-shaped components and reach depths of at least $26.5 \mathrm{~cm}$. These 3 thalassinidean species exhibit a degree of plasticity in their feeding and different trophic modes can be utilized in order to exploit the most advantageous food source available. The burrow of each species is described in terms of functional morphology with respect to feeding and discussed in relation to existing models of thalassinidean burrow architecture. A new approach to thalassinidean trophic classification based on individual components of burrow morphology rather than the complete burrow is proposed.
\end{abstract}

KEY WORDS: Thalassinidean - Callianassa Jaxea Upogebia B Burrow morphology $\cdot$ Feeding behaviour

\section{INTRODUCTION}

The thalassinidean shrimps are a ubiquitous component of the burrowing megafauna in marine and estuarine sediments but due to their elusive lifestyle and the deep and often complex nature of their burrows, these and other megafaunal species have often been overlooked by traditional sampling techniques. Many early thalassinidean studies concentrated on the ecology and burrow morphology of easily accessible intertidal species (MacGinitie 1930, 1934, Pearse 1945, Pohl 1946, Devine 1966). More recently, the bioturbatory abilities of these decapods have aroused much interest

\footnotetext{
•E-mail: Ian@dml.ac.uk
}

and work has taken place sublittorally in tropical lagoon environments where burrowing activity is evidenced by conspicuous surface mounds (Suchanek 1983, Tudhope \& Scoffin 1984, Vaugelas 1985, Colin et al. 1986). Progress includes the description of burrow morphology for a number of callianassid (Shinn 1968, Farrow 1971, Braithwaite \& Talbot 1972, Tudhope \& Scoffin 1984, Vaugelas 1984, Dworschak \& Pervesler 1988), upogebiid (Thompson \& Pritchard 1969, Frey \& Howard 1975, Swinbanks \& Murray 1981, Dworschak 1983), axiid (Pemberton et al. 1976) and calocaridid (Nash et al. 1984) species. Burrowing behaviour has also been documented for several thalassinidean species (MacGinitie 1930, 1934, Pohl 1946, Devine 1966, Ott et al. 1976, Nash et al. 1984, Rodrigues \& Hödl 1990). Feeding behaviour has been examined by direct 
observation (MacGinitie 1930, 1934, Pohl 1946, Devine 1966, Dworschak 1987, Witbaard \& Duineveld 1989) whilst other studies have determined feeding mechanisms indirectly from the structure and contents of the burrow and its lining, and from observations of surface activity (Suchanek 1983, 1985, Tudhope \& Scoffin 1984). The relationships between burrowing and feeding, however, are still poorly understood. There has been increasing speculation that thalassinidean feeding behaviour will influence burrow morphology lOtt et al. 1976, Suchanek 1985, Dworschak 1987, Griffis \& Suchanek 1991), but the difficulty in providing appropriate laboratory conditions in which to observe the behaviour of these shrimps, some of which can burrow to depths in excess of $3 \mathrm{~m}$ (Pemberton et al. 1976), has hindered ecological study. Recent work has seen the inception of a functional approach to the study of burrow architecture in relation to ecology and the influence of varying environmental conditions on intraspecific variation (Dworschak 1983, Suchanek 1985, Vaugelas 1990, Griffis \& Suchanek 1991). It is believed that an understanding of feeding behaviour and mechanisms, and of how the burrow morphology is used, would allow a more complete interpretation of thalassinidean ecology and evolution of burrow architecture.

In the soft, organically enriched sediments [typical organic carbon values of between 3.6 and $7.8 \%$ (Nickell 1992)] of Loch Sween, a sheltered sea loch on the west coast of Scotland, 3 species of thalassinidean, Callianassa subterranea (Montagu), Jaxea nocturna Nardo and Upogebia stellata (Montagu), were recognized as significant megafaunal burrowers (Atkinson 1987, 1989). At the inception of this study, ecological information for $U$. stellata and $J$. nocturna was scarce, although the burrow structure of 3 specimens of the latter from the Gulf of Trieste had been described by Pervesler \& Dworschak (1985). Atkinson (1986) gave preliminary details of the burrows of C. subterranea from the Clyde Sea area and this work was subsequently updated by Atkinson \& Nash (1990), although the functional importance of the burrow structure remained unclear. Witbaard \& Duineveld (1989) conducted a study of $C$. subterranea from the North Sea, presenting information on the ecology, biology and bioturbatory abilities of the species. The aim of the present study is to describe the burrow morphology and feeding behaviour of these 3 thalassinidean species and to relate trophic modes employed to burrow architecture. The results are then discussed in terms of their implications for models of thalassinidean burrow classification and a new approach to trophic classification is proposed.

Nomenclature of callianassids follows Manning \& Felder (1991).

\section{MATERIALS AND METHODS}

Burrow morphology. In situ investigations of burrow morphology of Callianassa subterranea, Jaxea nocturna and Upogebia stellata were carried out using SCUBA in Loch Sween on the west coast of Scotland $\left(56^{\circ} 0^{\prime} \mathrm{N}, 5^{\circ} 36^{\prime} \mathrm{W}\right)$. The loch is approximately $15 \mathrm{~km}$ long and runs in a south-west direction, opening into the Sound of Jura. Data were collected from 3 locations in the upper arms of the loch (Caol Scotnish, site 18; Sailean Mhòr, site 11; and Achnamara Arm), from Loch a'Bhealaich (at the base of Caol Scotnish arm, site 17) and from a fifth location in Tayvallich Anchorage (adjacent to Loch a'Bhealaich). Water depths at the study sites were 9 to $14 \mathrm{~m}$ with the exception of Tayvallich Anchorage which was $5 \mathrm{~m}$ deep. The substratum in the upper regions of the loch consists of fine, silt-clay mud with organic carbon values of 6.2 to $7.8 \%$ in Caol Scotnish and 3.6 to $4.7 \%$ at the other study locations. Further details of sites are given in Nickell (1992). Additional information and observations were collected from shrimps held in laboratory sediment microcosms of varying dimensions up to $140 \mathrm{~cm}$ diameter and $60 \mathrm{~cm}$ depth of sediment. Resin casts of the burrows were made using a technique described by Atkinson \& Chapman (1984). Polyester resin (manufactured by Scott Bader, marketed as SP701PA by Trylon Ltd, Wollaston, UK) was mixed with peroxide catalyst ( $2 \%$ by volume) in a $7 \mathrm{l}$ plastic watering can. In later casting exercises, $10 \%$ by volume of styrene monomer was also added to thin the resin and achieve better penetration of the fine burrow structures. On the sea bed, divers poured the resin mixture into ABS plastic collars which had been placed around selected burrow openings. Prior to casting, the positions and sizes of burrow openings were recorded on a slate and a small identifying flag was placed within each collar to enable casts to be reoriented when on the surface. Casts were dug out after 24 to 48 h hardening and were weighed, photographed and measured in the laboratory. The volumes of small blocks of resin from each casting exercise were measured by displacement of water. From these and their weights, the density of resin was calculated. Using the appropriate density figure and the weight of each cast, its volume could then be calculated. Surface area was estimated by visually dividing each cast into a series of geometric shapes. Each shape was measured and, using a program written by D. Henning, the surface area of each was calculated, taking into account the junctions between different shapes. The resultant figures were summed to give a value for the total surface area of the cast.

The terminology used to describe burrow morphology is as follows: A 'shaft' implies a vertical or domi- 
nantly vertical structure. A 'tunnel' is used to describe any other burrow structure with an oblique to horizontal orientation. It can be used in a general sense but where a specific orientation is implied, this will be stated. A 'chamber' is an expanded area of the burrow.

Feeding behaviour. The trophic modes utilized by Callianassa subterranea, Jaxea nocturna and Upogebia stellata were determined by direct and video observations (National WV 1350 remote control, low light sensitive camera and Panasonic Time Lapse Video Recorder NV-8051) of feeding behaviour. Specimens were maintained in the laboratory housed in narrow $(5$ to $10 \mathrm{~cm}$ ) Perspex sediment microcosms and where burrows impinged on the walls it was possible to record activity. Experimental shrimp were collected at various times between August 1989 and May 1991, either by SCUBA divers using an Alvey King Size bait pump to suck shrimp from their burrows, a technique similar to that described by Manning (1975), or using a ship-deployed anchor dredge. The majority of specimens of $C$. subterranea and all specimens of $J$. nocturna were caught in Loch Sween. The remaining $C$. subterranea and all $U$. stellata were collected around the Isle of Cumbrae, off Lion Rock $\left(54^{\circ} 45^{\prime} 15 \mathrm{~N}, 4^{\circ} 53^{\prime} 90 \mathrm{~W}\right)$ and at White Bay $\left(54^{\circ} 47^{\prime} 70\right.$ N, $\left.4^{\circ} 54^{\prime} 50 \mathrm{~W}\right)$.

\section{RESULTS}

\section{Burrow morphology}

\section{Callianassa subterranea}

A total of 22 burrow casts of Callianassa subterranea were recovered from Loch Sween and laboratory sediment microcosms. Some of the casts were incomplete due to breakages during recovery or to insufficient resin penetration; however, all were used to identify the features characteristic of the burrows of this species. Morphometric data for 8 casts, which were considered to be reasonably complete and representative of the typical burrow type, are given in Table 1.

A typical burrow cast of Callianassa subterranea (C6 in Table 1) is shown in

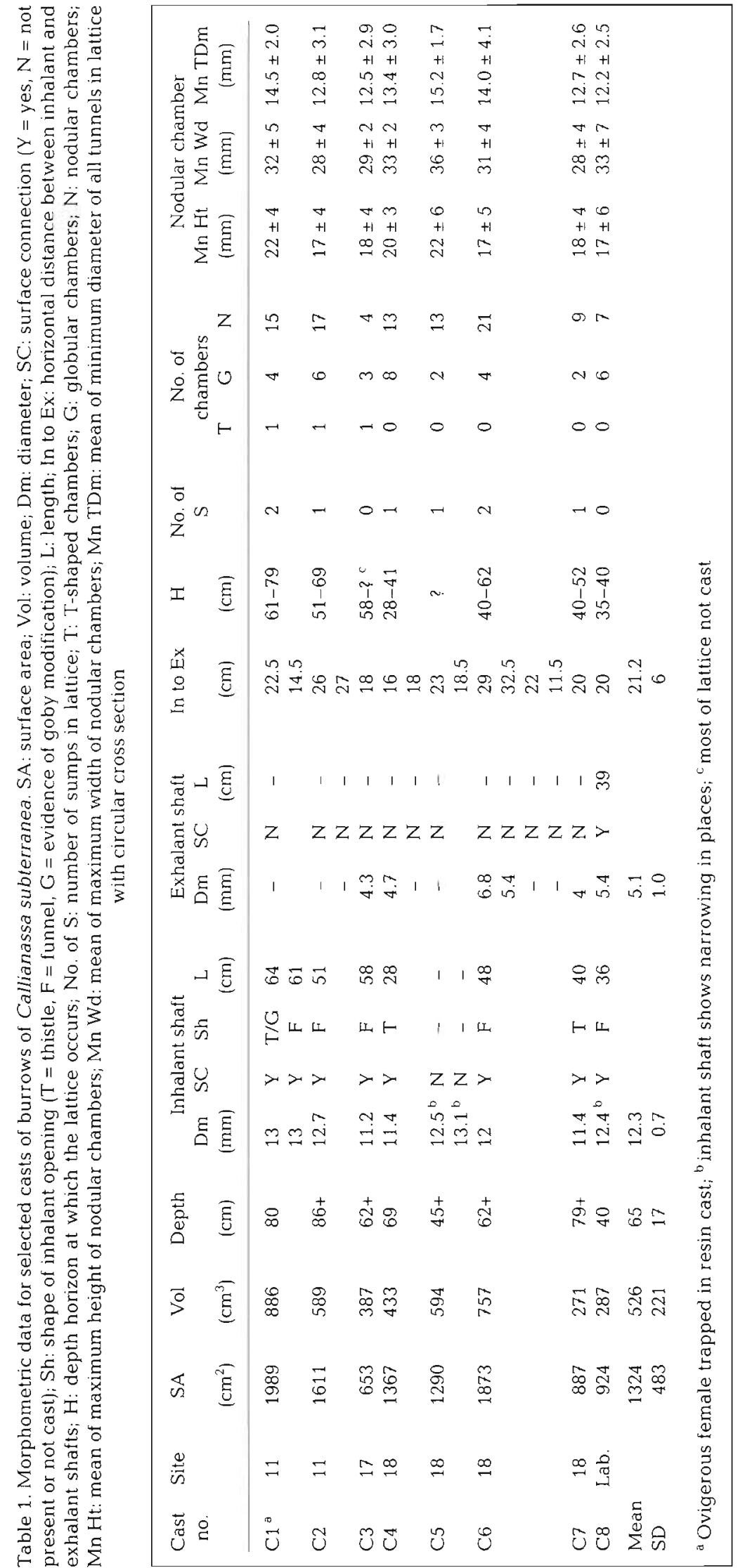




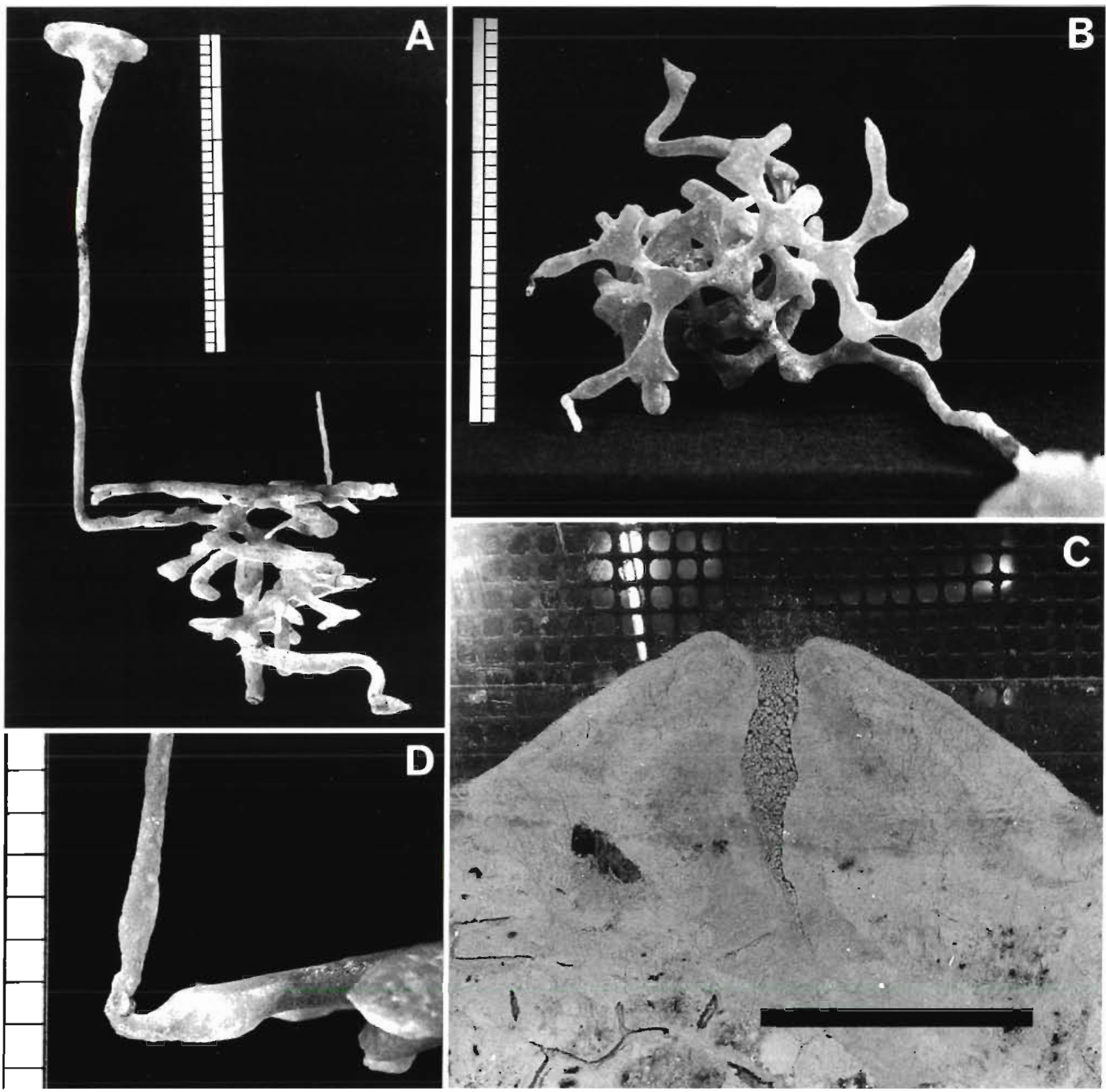

Fig. 1. Resin casts of burrows of Callianassa subterranea. (A) Lateral and (B) plan view of a typical burrow (no. C6); scale bars = $30 \mathrm{~cm}$. (C) Percolation mound; scale bar $=10 \mathrm{~cm}$. (D) Base of the exhalant shaft; $5 \mathrm{cale}$ bar divisions $=1 \mathrm{~cm}$

Fig. 1A, B. Laboratory casts were morphologically similar to those from the field but were depth restricted by the sediment microcosms. In a generalized burrow there is a wide vertical shaft which extends from the sediment surface to a horizontal lattice of tunnels and chambers. Amongst the measured casts, the mean diameter of this shaft is $12.3 \pm 0.7 \mathrm{~mm}(\mathrm{n}=8)$. Laboratory observations indicate that shaft diameter is closely related to the shrimp's dimensions; thus, the figures suggest that all of these burrows were constructed by shrimp of similar size. Specimens responsible for casts C8 and a second incomplete cast (for which no morphometric data are given), taken from the laboratory, had carapace length:diameter-of-inhalant-shaft ratios of $1.05: 1$ and $1.13: 1$, respectively.

The wide vertical shaft has an inhalant function. Adjacent to the connection of the shaft with the lattice, there is an enlargement of the horizontal tunnel, forming either a simple dilation of the tunnel or 2 opposing pocket-like chambers, in which coarse shell fragments 
are occasionally found. A second type of vertical shaft, which is functionally exhalant, is also present with a diameter of less than half that of the inhalant shaft (mean diameter $=5.1 \pm 1 \mathrm{~mm}, \mathrm{n}=8$ ). This shaft has smooth but undulating walls and the 'corkscrew-like' nature of these undulations suggests that it may have been constructed as a tight spiral, probably by narrowing of a wider shaft. Evidence from burrow casts indicates that there may be as many as 4 exhalant shafts, aithough they are not all concurrently in use. Some extend part or all the way to the surface whilst others are blocked at the level of the lattice, possibly due to incomplete casting. Laboratory observations, however, confirm that during the shrimps' normal activity these narrow shafts are periodically filled with pelletized sediment resulting in surface 'percolation' mounds, apparently blocked but through which water and fluidized sediment can pass (Fig. 1C). At the bottom of the exhalant shaft a distinctive burrow feature is found: the base of the shaft is J-or hook-shaped and is connected to a horizontal finger-like tunnel which is slightly expanded just prior to the connection (Fig. 1D). Where more than one exhalant shaft is present, the associated finger-like tunnels usually occur in the uppermost plane of the lattice and are radially distributed around the central tunnels and chambers, giving the lattice a stellate appearance when viewed from above (Fig. 1B). Atkinson \& Nash (1990) reported that these tunnels extended outwards from the lattice rather like spokes from a hub.

In 4 cases, 2 inhalant shafts were identified within a single cast. In one of these casts (C1), an ovigerous female was found trapped in the resin. In another (C5), neither of the shafts was completely cast; however, one riser showed signs of narrowing at its base, suggesting that if the shaft was functional, it may have changed from being inhalant to exhalant. Similar narrowing was noted in cast C8 and 2 further incomplete casts

The mean distance between inhalant and exhalant shafts is $21.2 \pm 6.0 \mathrm{~cm}$, generally indicative of the diameter of the area occupied by the lattice, since both types of shaft tend to occur peripherally. Exhalant shaft openings usually occur in a sediment mound which may be very variable in size. In the laboratory exhalant mounds reached heights of up to $6 \mathrm{~cm}$ with a diameter of $20 \mathrm{~cm}$ at the base. Burrow casts from Caol Scotnish, however, tended to have rather insignificant mounds, often less than $5 \mathrm{~cm}$ high with basal diameters of less than $15 \mathrm{~cm}$, whilst those from Sailean Mhò were associated with mounds up to $20 \mathrm{~cm}$ high and $40 \mathrm{~cm}$ in diameter. The openings of both shaft types may be funnel-shaped (Fig. 1A) or thistle-shaped (as described by Atkinson \& Nash 1990). Inhalant shaft openings are usually associated with a funnel-shaped crater, which may or may not occur in a sediment mound. If present, these mounds are often smaller than those associated with exhalant openings. Occasionally, the black goby Gobius niger was found to have modified a burrow opening, resulting in a bulbous chamber just below the inhalant funnel (e.g. cast C1; see Table 1), and observations in the field suggest that these fish are commonly utilizing the burrow openings as a temporary refuge. The only other symbionts (the term is used in a general sense without necessarily implying mutual benefit, as the nature of the association was not determined) found in the burrows of Callianassa subterranea were occasional errant polychaetes, particularly polynoid worms, but these do not appear to influence burrow architecture.

The lattice (Fig. 1B) at the base of the vertical shaft is made up of a series of tunnels with circular cross section and expanded chambers, as identified by Atkinson \& Nash (1990). Table 1 shows the depth horizon within which the major part of the lattice occurs for each burrow. The 8 casts for which morphometric data were collected had lattice tunnels with mean diameters of between $12.2 \pm 2.5$ and $15.2 \pm 1.7 \mathrm{~mm}$. The tunnels are arranged in a number of closely stacked, horizontal planes, which are connected by oblique tunnels or shafts descending at angles of between $20^{\circ}$ and $90^{\circ}$ from horizontal. Centrally, the tunnels meet at approximately right angles and a nodular chamber occurs at the intersection. Dimensions of these chambers are given for the 8 casts in Table 1. Quadripartite junctions occur most frequently in the centre of the cast with occasional quinquepartite junctions, whilst tripartite junctions are more common around the periphery of the lattice. Blind-ending branches off the main tunnel which are expanded to form elongated $\mathrm{T}$-shaped or globular chambers are also present. Dimensions for these chambers are not given in Table 1 due to the variability in size observed. Centrally in the lattice, there is also a vertical, downwardly directed, blindending shaft or 'sump'. Less commonly, 2 of these structures occur and coarse shell and mineral debris, together with faecal material, is frequently found at the bottom.

Several of the resin casts had breakages or a partially cast structure at the base of the lattice, indicating that the burrow had a deeper portion which was not recovered. It is thus likely that the value for mean depth of burrows ( $65 \pm 17 \mathrm{~cm}$, Table 1$)$ is conservative. In 7 casts, including $\mathrm{C} 2, \mathrm{C} 4, \mathrm{C} 5, \mathrm{C} 6$ and $\mathrm{C}$, another tunnel or shaft was present extending from the bottom of the lattice at angles of between $0^{\circ}$ and $90^{\circ}$ from the horizontal plane. Occasional side branches and globular chambers were associated with these structures and in cast C5 the extension was $69 \mathrm{~cm}$ long, reaching a depth of $45 \mathrm{~cm}$. 
Table 2. Morphometric data for selected casts of burrows of Jaxea nocturna. Dm: diameter of vertical shaft with circular cross section $\mathrm{Ht}$ : height; Wd: width

\begin{tabular}{|c|c|c|c|c|c|c|c|c|}
\hline \multirow{2}{*}{$\begin{array}{l}\text { Cast } \\
\text { no. }\end{array}$} & \multirow[t]{2}{*}{ Site } & \multirow{2}{*}{$\begin{array}{l}\text { Surface area } \\
\qquad\left(\mathrm{cm}^{2}\right)\end{array}$} & \multirow{2}{*}{$\begin{array}{c}\text { Volume } \\
\left(\mathrm{cm}^{3}\right)\end{array}$} & \multirow{2}{*}{$\begin{array}{l}\text { Depth } \\
(\mathrm{cm})\end{array}$} & \multirow{2}{*}{$\begin{array}{c}\text { No. of surface } \\
\text { openings }\end{array}$} & \multirow{2}{*}{$\underset{(\mathrm{mm})}{\mathrm{Dm}}$} & \multicolumn{2}{|c|}{ Mean tunnel } \\
\hline & & & & & & & $\mathrm{H} t(\mathrm{~mm})$ & $\mathrm{Wd}(\mathrm{mm})$ \\
\hline $\mathrm{J} 1$ & Lab. & 2382 & 1312 & 51 & 3 & 11.8 & 15 & 29 \\
\hline $\mathrm{J} 2$ & Lab. & 3895 & 2030 & 28 & 7 & 14.2 & 16 & 27 \\
\hline $\mathrm{J} 3$ & 11 & 4780 & 2315 & 70 & 2 & 11.6 & 19 & 31 \\
\hline $\mathrm{J}_{4}$ & 11 & 1357 & 209 & 39 & 1 & 10.1 & 17 & 28 \\
\hline \multicolumn{2}{|c|}{ Mean $\pm \mathrm{SD}$} & $3686 \pm 1213$ & $1886 \pm 517$ & $50 \pm 21$ & & $12.5 \pm 1.4$ & & \\
\hline
\end{tabular}

\section{Jaxea nocturna}

Three apparently complete casts of the burrows of Jaxea nocturna were recovered during the study but 2 of these were laboratory examples. Morphometric data for these casts, together with a fourth incomplete cast, are given in Table 2. The following descriptions are based on the morphology of these and several incomplete casts recovered from Caol Scotnish and Sailean Mhòr, together with observations of field and laboratory burrows.

A burrow cast showing features typical of Jaxea nocturna is shown in Fig. 2A, B. Burrow casts have between 1 and 7 surface openings. Additional short, blind-ending oblique tunnels extend toward the surface from the main burrow, corresponding with burrow entrances which are blocked by plugs of sediment at the surface. Most of the openings are associated with low sediment mounds (less than $5 \mathrm{~cm}$ high), which sometimes have a characteristic crenate appearance caused by the shrimp bulldozing sediment between its chelipeds onto the surface. These openings are connected to tunnels which descend at angles of $20^{\circ}$ to $45^{\circ}$ from horizontal, and converge to become a wide, spirally orientated, gently sloping main tunnel, subcircular in cross section with a rough, arched roof and a smoother, flattened or slightly concave floor (maximum recorded dimensions: height $26 \mathrm{~mm} \times$ width $43 \mathrm{~mm}$ ). The remaining surface openings (usually 1 or 2 ) are funnel-shaped and are associated with vertical shafts which join the main tunnel at approximately 20 to $90 \mathrm{~cm}$ below the sediment surface. Some of the vertical shafts have 2 short leaf-like side branches, usually towards the bottom of the shaft (Fig. 2C). Unlike the main tunnel, this shaft has a circular cross section (10.1 to $16.0 \mathrm{~mm}$ in diameter) and distinctively roughened walls with small peaks and pits on the surface. Occasionally 2 of these shafts deviate from vertical and intersect, forming an enlarged, bulbous chamber with a rough, nodular surface. Two or three enlarged chambers with horizontal floors are present within the main tunnel and are often incompletely filled by the resin, either due to their large size or to the presence of a water lock. The main tunnel branches occasionally, becoming enlarged at the intersection, and the distal ends of the branches are narrower and more circular in cross section, corresponding more closely to the diameters of vertical shafts. The main tunnel continues at angles of between $0^{\circ}$ and $40^{\circ}$ from horizontal. Pieces of shell and mineral debris protrude into the burrow and similar debris is found in the burrow openings. In the laboratory burrow depth is restricted by the depth of sediment available; however, field casts indicate that burrows can reach to depths in excess of $92 \mathrm{~cm}$.

Cast J3, an apparently complete burrow of Jaxea nocturna, was associated with the burrows of the Norway lobster Nephrops norvegicus and the echiuran worm Maxmuelleria lankesteri. The figures for surface area and volume of this burrow (Table 2) include the $J$. nocturna and $M$. lankesteri burrows but not the $N$. norvegicus burrow. The uppermost level of the burrow system displays all the characteristics of a $N$. norvegicus burrow, as described by Rice \& Chapman (1971). From the floor of the $N$. norvegicus burrow a short shaft with circular cross section (diameter $11.6 \mathrm{~mm}$ ) descends into a series of meandering, gently sloping tunnels. These have a generally spiral orientation and the typical sub-circular cross section (height $19 \mathrm{~mm} \times$ width $31 \mathrm{~mm}$ ) seen in other $J$. nocturna burrows. The entrapment of a shrimp in the cast confirmed the identity of the burrower The tunnels appear to occur in layers, with horizontal or gently sloping sections, dipping at angles of less than $15^{\circ}$. linked by oblique tunnels or shafts $\left(40^{\circ}\right.$ to $\left.90^{\circ}\right)$ which have circular cross sections. In the second lowest layer the tunnel additionally had tree-bark-like striations typical of a $M$. lankesteri burrow, and an escape trace covered in green mucus (Nickell 1992, Nickell et al. 1995) confirmed the presence of this species also. Although the burrow displays many of the features typical of $J$. nocturna, the overall burrow architecture is strongly influenced by the other 2 occupying species

Cast J 1 was the only burrow for which the carapace length of the occupant was known. Comparing the ratio of carapace length $(13 \mathrm{~mm})$ to vertical shaft diameter $(11.8 \mathrm{~mm})$ gives figures of 1.10:1. Specimens of 

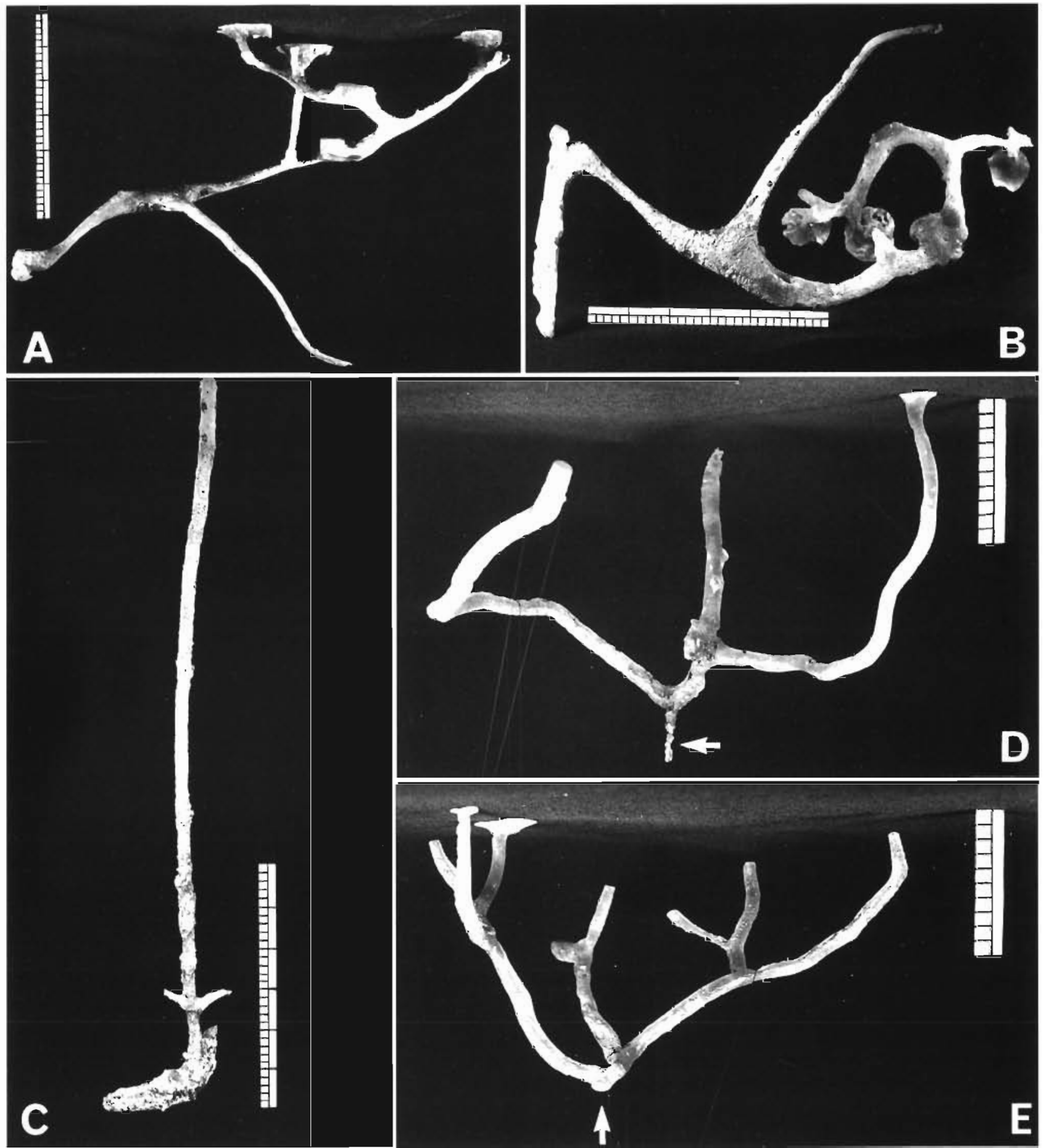

Fig. 2. (A) Lateral and (B) plan views of a laboratory cast of a Jaxea nocturna burrow (no. J1); (C) vertical shaft from a $J$. nocturna burrow cast in the field; scale bars $=30 \mathrm{~cm}$. (D) Lateral view of Upogebia burrow cast no. U1 (arrow indicates small vertical shaft probably not constructed by the shrimp) and (E) U2 (arrow indicates cast breakage); scale bars $=10 \mathrm{~cm}$

Jaxea nocturna are rarely caught in resin casts but of 4 animals trapped, 3 were in association with Maxmuelleria lankesteri. In addition, 14 casts of burrows of $M$. lankesteri casts were recovered which showed evidence of modification by $J$. nocturna.

\section{Upogebia stellata}

Burrows of Upogebia stellata were cast at only 1 location in Loch Sween, in Tayvallich Anchorage. Although extensive casting was done at other sites in 
Table 3. Morphometric data for selected casts of burrows of Upogebia stellata

\begin{tabular}{|lccccc|}
\hline Cast no. & Surface area $\left(\mathrm{cm}^{2}\right)$ & Volume $\left(\mathrm{cm}^{3}\right)$ & Depth $(\mathrm{cm})$ & No. of surface openings & Tunnel diam. (mm) \\
\hline U1 & 461 & 103 & 26.5 & 2 & 13.9 \\
U2 & 444 & 86 & 19 & 3 & 11.8 \\
\hline
\end{tabular}

the loch, none of the casts produced could be attributed to this species. Three casts were recovered, all of which were incomplete. Details of cast features and dimensions (Table 3) are taken from these and from laboratory observations of burrows. In casts U1 and U2 resin penetration was good but sections of the resulting burrow casts were lost during recovery. In cast U3, the resin did not penetrate very deeply, possibly because of a blockage in the burrow, but the main features of the cast resembled those of the other two. No morphometric data are given for this cast.

Cast U1 (Fig. 2D) is made up of a large U-shaped section with an additional shaft extending towards the surface from the base of the $U$. The angles between the junction of this shaft and the main $U$ are about $90^{\circ}$ and the junction is slightly expanded to form a small chamber. There is evidence of another shaft extending vertically downwards from the deepest section of the burrow but it has been incompletely cast and its morphology suggests that it may not have been constructed by the shrimp. Cast $\mathrm{U} 2$ (Fig. 2E) is almost $\mathrm{Y}$-shaped in construction but the lowest section, the tail of the $Y$, is missing. Four additional branches extend towards the surface and 2 of these branch again, forming further Y-shaped structures. The angles between branches at each of the junctions are always less than $90^{\circ}$. The main branch does not have chambers comparable to those of a Callianassa subterranea burrow, but along its length there are 3 slightly expanded areas which may be used for turning. In laboratory burrows, however, distinct chambers are present within tunnels and at the intersections between branches.

The burrow openings are small funnel-shaped structures, flush with the sediment surface. In all 3 casts, there is a slight narrowing of the shaft diameter just below the funnel and this feature is consistent with laboratory observations of restricted burrow openings. In the casts, U1 and U2, shafts are present which terminate just below the sediment surface. It is possible that these were originally connected to the sediment surface but had been blocked or partially blocked by the shrimp, or that the connection to the surface had not been completed at the time of casting.

\section{Feeding behaviour}

\section{Callianassa subterranea}

Callianassa subterranea is primarily a deposit feeder. Feeding takes place entirely within the burrow and once a burrow is established, much of the subsequent burrowing activity is for the purpose of obtaining food. Feeding occurs primarily within the lattice. The chelate first and second pereiopods are used to loosen sediment from the burrow wall, floor or ceiling. The third pereiopods are also used, the expanded propodus of each acting like a knife to cut into the sediment. The fourth pereiopods are held against the burrow wall, giving lateral stability, and the fifth extend behind to brace the animal in position. The second pereiopods, assisted by the third, pick up loosened sediment. The second pereiopods are fringed with long setae, particularly along the ventral margins, thus forming a setal basket in which the sediment is held in front of the mouthparts. Sediment may also be transferred directly to the mouthparts by the second pereiopods. Alternate movements of the right and left third maxilliped draw sediment into a channel created by the slightly expanded meri and ischia of these limbs. The dactyl, propodus and carpus move as a unit whilst the merus and ischium remain almost stationary, apposed so that their ventral margins meet. The crista dentata meets its opposite partner along the midline like a toothed jaw and may serve to break down small lumps of sediment. The second maxilliped imitates the movement of the third and helps to draw sediment lumps and particles towards the mouth. The third maxilliped is also used to clean particles off the setae of the second pereiopods. During feeding some sediment overflows from the mouthparts and it is possible that this is material rejected as a result of particle size selection

After feeding on material for anything from a few seconds to several minutes, the sediment is either dropped or gathered up into a bolus held in a 'basket' formed by the third maxillipeds and the first and second pereiopods. It is moved to another location and is worked into the burrow wall or used to backfill a tunnel or shaft, or loose particles may be vented from the burrow by means of a pleopod generated current. The shrimp positions itself at the base of the exhalant shaft 
with its abdomen within the finger-like tunnel and the discoid pleopods, which when expanded closely match the tunnel diameter, beat metachronally to produce a posteriorly directed, pulsed water current. During this activity the setal fringe of the second pereiopods will catch suspended material which is periodically removed by the third maxillipeds and ingested.

\section{Jaxea nocturna}

Jaxea nocturna is also a deposit feeder. Feeding occurs at all depths within the burrow, but $J$. nocturna may also take material from the surface. Laboratory observations demonstrated that surface activity was restricted to the hours of darkness, although in the field these shrimp have been seen in burrow openings during the day. Patterns in the sediment around the burrow opening indicated that, in some cases, large quantities of material had been pulled sub-surface using the chelipeds. This was distributed throughout the burrow by bulldozing sediment along tunnel floors. In addition, fish meal pellets left beside the burrow opening were dragged into the burrow and worked into the floor of a tunnel, although shrimp were not observed feeding on this material. Attempts to elicit a similar response using other organic material, such as macroalgae (Laminaria digitata and Fucus vesiculosus) and leaf litter, common on the sediment surface at the field sites, were unsuccessful.

The shrimp often feeds whilst moving through the burrow. Jaxea nocturna lacks much of the specialized setation present on the limbs of Callianassa subterranea and consequently adopts a different feeding mechanism. The chelipeds which are not involved in feeding behaviour are held anteriorly and, using the second pair of pereiopods, material is collected from the burrow floor. Some sediment is transferred directly to the third maxillipeds, but the slender second pereiopods, which have short, pointed dactyls, are unable to pick up large lumps of sediment. Instead, small amounts of material are thrown upwards and resuspended in front of the mouthparts. The dactyl, propodus and carpus of each third maxilliped operate simultaneously and, with alternate movements of the right and left hand side, the third maxillipeds capture sediment particles and draw them into the other mouthparts. Periodically, the third maxillipeds extend forward and clean material of the pereiopods or pick up sediment directly from the burrow floor for ingestion. Rhythmic beating of the second maxilliped probably creates a current which helps to draw smaller particles towards the mouth.

During feeding or whilst bulldozing sediment the shrimp may produce a current from the mouthparts, possibly generated by the flagella of the exopods of the maxillipeds or by the scaphognathites, which carries a plume of sediment particles and exits laterally over the dorsal margins of the third maxillipeds. It is possible that size selection of material for ingestion is taking place but it seems more likely that the shrimp is cleaning the gills and mouthparts of clogged sediment.

\section{Upogebia stellata}

Upogebia stellata has the ability to both suspension and deposit feed. Suspension feeding usually takes place in one of the turning chambers of the burrow. but has also been observed in the burrow mouth. The shrimp maintains its position using the third, fourth and fifth pereiopods. The abdomen extends out of the turning chamber into a region of circular tunnel where the pleopods match the tunnel dimensions. The chelipeds are held against the burrow wall anterior to the shrimp with the second pereiopods below and between them, thus forming a setal basket which fills the diameter of the chamber. A posteriorly directed current is established by beating of the pleopods and material is captured by the setae. The third maxillipeds intermittently sweep downwards over the setal basket, the dense fringing setae acting like a comb to remove particles and transfer them to the other mouthparts, assisted by beating of the second maxillipeds. It is possible that the setal basket may act as a primary filter, rejecting large particles, and only material lodging in or passing through the setae will be ingested

Resuspension feeding, similar to that of Jaxea nocturna, has been observed for this species. The shrimp removes sediment from the burrow wall and carries the material, using the third maxillipeds and the first and second pereiopods, to a turning chamber. There the shrimp uses its first and second pereiopods to fluidize sediment which is thrown up in front of the mouthparts. Pleopod beating draws the material through the setal basket and the third maxillipeds transfer particles to the mouth as described previously. Upogebia stellata is also capable of deposit feeding in a manner similar to that described for Callianassa subterranea and will use this method particularly in the initial phases of burrow establishment. In addition, whilst bulldozing material out of the burrow and away from an opening, a plume of sediment is occasionally seen emerging from the mouthparts and exiting over the lateral border of the third maxilliped. This activity was similar to that observed for $J$. nocturna and may have an identical function. 


\section{DISCUSSION}

\section{Functional morphology of burrows}

\section{Callianassa subterranea}

Callianassa subterranea from the organically enriched sediments of Loch Sween appears typical of the callianassids (Suchanek 1985, Griffis \& Suchanek 1991) in that it is primarily a deposit feeder. The description by Dworschak (1987) of feeding behaviour for C. tyrrhena is almost identical to that for C. subterranea. The burrow of $C$. subterranea is a dynamic structure which continually changes shape as the shrimp processes sub-surface sediment for the purpose of obtaining food, and burrow architecture is strongly reflective of this trophic mode. Lattice depth and overall burrow depth, of which the maximum recorded value of $86 \mathrm{~cm}$ is almost certainly an underestimate, suggest a nutritional requirement for sub-surface organic matter. The tight radial orientation of tunnels and chambers and close stacking of different levels of the lattice means that the shrimp can efficiently utilize a given volume of sediment, as noted by Atkinson \& Nash (1990). The small diverticula arising from the base of the inhalant shaft may function as dumping areas for pieces of inorganic debris which fall or are inadvertently drawn into the burrow and are too heavy to eject onto the surface. The vertical sump has a similar function and its location in the centre of the lattice means that it is easily accessible from all areas of the burrow. Lateral burrow extensions, where present, allow the shrimp to move horizontally through the sediment and establish a new lattice in nutritionally unexploited sediment. Field and laboratory observations have confirmed that burrows migrate through the sediment matrix as new openings are established and old ones abandoned.

Laboratory observations for Callianassa subterranea, indicating that the diameter of the burrow tunnels and shafts is reflective of the size of the inhabitant, are in agreement with observations for other callianassid species (Pohl 1946, Dworschak \& Pervesler 1988, Griffis \& Chavez 1988, Witbaard \& Duineveld 1989, Witbaard 1991, Dr A. Rowden pers. comm.). It is likely that the wide diameter of the inhalant shaft is maintained to ensure an adequate route for flow of surface water into the burrow and the funnel-shaped crater at the surface is the result of this inward flow displacing sediment. Devine (1966) referred to similar structures created by C. filholi as 'erosion craters'. This study suggests that the activity of the gobiid fish Gobius niger is capable of making significant modifications to the burrow openings and is responsible for most of the observed dilations of the inhalant shaft. In the field, Pomatoschistus minutus has been observed in burrow openings of $C$. subterranea (Atkinson 1989 pers. obs.) and may also modify upper parts of the burrow.

The narrow exhalant shaft is not maintained constantly open, but water and fluidized sediment can still percolate through and the shaft can easily be reopened by the animal-generated currents. The positions of the vertical shafts in the uppermost plane of the lattice means that between the inhalant and exhalant shafts, a basically U-shaped connection is maintained with the sediment surface. This allows effective burrow irrigation or clearing of waste material and debris and also some suspension feeding. Construction of the narrow exhalant by modification of a wider shaft has been suggested for other callianassids (Frey et al. 1978, Dworschak \& Pervesler 1988, D. Swift pers. comm.). The reason for reducing the diameter of the exhalant shaft may be that the shrimp is making use of the Venturi effect whereby the velocity of a fluid, passing from one tube into a another of smaller diameter, will be increased. This may enhance the potential of the irrigation current to carry particles in suspension and thus increase the efficiency of sediment ejection. Other authors have reported the presence of narrow exhalant shafts in callianassid burrows (Braithwaite \& Talbot 1972, Dworschak \& Pervesler 1988, Witbaard \& Duineveld 1989) and the morphologies of the shafts and finger-like tunnels at their base are strikingly similar to those found in burrows of Callianassa subterranea. It should be noted, however, that water flow through the burrow may also be generated passively by external currents (Allanson et al. 1992).

Suchanek et al. (1986) resin cast burrows of an unidentified callianassid species from a tropical lagoon. They suggested that the burrow was acting as a sediment trap, a hypothesis supported by other authors (Suchanek 1983, Poore \& Suchanek 1988, Witbaard \& Duineveld 1989, Vaugelas 1990). Particles falling or subducted into the funnel-shaped openings by animalgenerated currents may be used directly or indirectly (via the growth of micro-organisms) as food. Suchanek et al. (1986) believed that as the carbonate sands which these shrimp inhabit are of little nutritional value, the laterally extensive burrow morphology allowed these shrimp to make use of surface organic material and maximize the capture of material drifting across the sediment/water interface. It seems logical that the degree of lateral extension exhibited by a burrow may be related to the importance of surface-derived material for the nutrition of the occupying species.

Witbaard \& Duineveld (1989) supported the sediment trap idea for Callianassa subterranea and resin casts from the southern North Sea revealed that burrows frequently had several funnel-shaped openings and were only in the region of $25 \mathrm{~cm}$ deep, in contrast 
to the deeper burrows with fewer openings from Loch Sween. In addition, specimens of $C$. subterranea taken from Loch Sween and held in tanks containing a sandy substratum have been observed taking sediment from around burrow openings after a suspension of algal cells was added to the sediment microcosm tank and allowed to settle (Dr D. Hughes pers. comm.). This indicates that $C$. subterranea is capable of utilizing different food sources under varying environmental conditions and that a high degree of intraspecific plasticity is possible, both in the use of trophic modes and burrow architecture. Atkinson \& Nash (1990) suggested that differences seen in C. subterranea from Loch Sween and the North Sea might reflect differing burrowing strategies in sediments of differing granulometry and organic content. Griffis \& Chavez (1988) came to similar conclusions regarding the callianassids Neotrypaea californiensis and $N$. gigas. These authors believed that the burrow morphology of these 2 species might be influenced by a wide range of environmental factors, including sediment type and food availability, and biological factors such as population density and community composition.

Pohl (1946), Devine (1966) and Powell (1974), working on the callianassids Callichirus major, C. filholi and Neotrypaea californiensis, respectively, believed that the diets of these shrimp were derived, at least in part, from the sediment surface and the water column. Devine (1966) also suggested that $C$. filholi was adapting its feeding behaviour in response to depleted carbon levels within the sediment. Vaugelas et al. (1986) indicated that there was a relationship between organic carbon content of sediments and bioturbatory activity of the callianassid species Glypturus armatus, with less sediment being processed in organically enriched conditions. This is in accordance with findings for $C$. subterranea in Caol Scotnish, Loch Sween (Nickell 1992), and provides further support for an intraspecific trophic plasticity hypothesis.

\section{Jaxea nocturna}

Casts recovered from Loch Sween and the laboratory are similar to those described by Pervesler \& Dworschak (1985) from the Gulf of Trieste (Adriatic Sea) with only minor differences. Pervesler \& Dworschak. (1985) indicated that burrows of this species have 2 main openings connected to vertical shafts but the present study indicates that more can be present. Fourteen were recorded from a single burrow system in the laboratory, of which up to 8 were active at any one time. In addition, openings are not always associated with vertical shafts. Some are connected to oblique tunnels and it is these that are more commonly associ- ated with a sediment mound caused by the shrimps' bulldozing activities. It is possible that Jaxea nocturna from the Gulf of Trieste has a lower dependence on surface derived material, since the burrow architecture is less adapted for the movement of sediment into and out of the burrow. The rest of the described burrow morphology agrees well with the burrow casts taken during this study.

Crenate mounds similar to those constructed by Jaxea nocturna are produced by alpheid shrimps (Dworschak \& Ott 1993), suggesting that they too bulldoze sediment. Like $J$. nocturna, burrows of Alpheus spp. show elliptical cross sections which may result from the shrimps' continued activity, walking, feeding and bulldozing sediment, as described for the crab Goneplax rhomboides (Atkinson 1974). This suggests a degree of permanence to such burrows rather than the dynamic burrow system of a primarily sub-surface deposit feeder like Callianassa subterranea. Similar to observations made during this study, Pervesler \& Dworschak (1985) noted that some deeper tunnels of $J$. nocturna burrows had a more circular cross section before ending blindly, indicating that these may have been newly constructed. It is likely that a circular cross section is caused at least in part by the shrimps' morphology and burrowing behaviour. In the large complex burrow cast containing Nephrops norvegicus, Maxmuelleria lankesteri and $J$. nocturna, successively deeper levels of the $J$. nocturna burrow were linked by short vertical shafts of circular cross section. Maintenance of narrow shafts appears to be a necessity allowing the animal contact with the burrow walls to enable it to climb these shafts. It is possible that the frequent association noted between burrows of $M$. lankesteri and $J$. nocturna may be of nutritional benefit to the crustacean as the deposit feeding activity of the worm brings surface sediment into the burrow (Hughes et al. 1993) which might then become available to $J$. nocturna.

Considering the massive dimensions of the burrow of Jaxea nocturna relative to the animal's size and the reduced nature of its pleopods and lack of setation, it is likely that the ability of this species to suspension feed (sensu strictu) is limited. A feeding technique, similar to the resuspension technique used by Jaxea nocturna, has been described for Callianassa filholi (Devine 1966) and Dworschak (1987) observed Upogebia pusilla feeding on material which had been collected and resuspended within the setal basket. Pervesler \& Dworschak (1985) suggested that the gut contents, general burrow shape and poor fit of J. nocturna's dimensions to the burrow diameters was indicative of deposit feeding. In addition, they speculated that the enlarged chambers represented attempts by the shrimp to seek out layers of sediment rich in organic carbon. 
Enlarged burrow tunnels have aiso been described for the thalassinidean Callianidea laevicauda although the trophic mode of this species has not been firmly established. It has been observed taking material from the sediment surface, in addition to ingesting material from within the burrow (Rodrigues 1983, in Griffis \& Suchanek 1991). It is possible that, like $J$. nocturna, the burrow morphology of this species is adapted to allow exploitation of surface and sub-surface material.

Scavenging of organic material from the sediment surface has also been observed for Corallianassa longiventris and Axiopsis serratifrons (Suchanek 1985, Manning 1987, Dworschak \& Ott 1993). Nardo (1847) and Pesta (1918) (both cited in Pervesler \& Dworschak 1985) suggested that Jaexa nocturna is active near or on the sediment surface at night and in the Adriatic $J$. nocturna was only caught in trawls at night (Dr C. Froglia pers. comm.). The present study has confirmed that the shrimp do leave the burrow, particularly at night, for the purposes of sediment movement in or out of the burrow. Studies on Calocaris macandreae have revealed that it will take macrofauna into the burrow for burial, possibly for the purpose of gardening microorganisms to enhance the burrow environment for deposit feeding (Buchanan 1963, Nash et al. 1984). Suchanek (1985) reported hand-feeding seagrass to Glypturus acanthochirus and Dworschak \& Ott (1993) found seagrass debris in the burrows of this species and Axiopsis serratifrons. In these examples, however, the shrimp may be consuming the scavenged material directly and further empirical data are required to provide unequivocal evidence of gardening. In the case of $J$. nocturna in the present study, scavenging behaviour may have been in response to the lower organic carbon levels [<2.5\% (Nickell 1992)] and confined conditions of sediment tanks in the laboratory.

\section{Upogebia stellata}

The burrows of Upogebia stellata, as determined by laboratory observations of burrows and by resin casting, are fairly simple and U- or Y-shaped which is typical of the upogebiids as a group. Almost all the burrows of Upogebia spp. so far described conform to a general pattern and burrow casts of $U$. pusilla (as $U$. litoralis) (Ott et al. 1976, Dworschak 1983), U. deltaura (Dworschak 1983), U. pugettensis (MacGinitie 1930) and $U$. affinis (Frey \& Howard 1975) all show the basic $\mathrm{U}$ or $\mathrm{Y}$ shape and are considered to be fairly permanent structures (Dworschak 1983, Vaugelas 1990). Filtering is the dominant mode of feeding in the upogebiids (MacGinitie 1930, Schaefer 1970, Powell 1974, Dworschak 1987, Scott et al. 1988), as is the case in $U$. stellata. Large quantities of sediment, therefore, are not being moved and the burrow is a refuge adapted for feeding by the efficient circulation of water through it (Vaugelas 1990). Although the permanent burrow structure of $U$. stellata would seem to be ideal for the development of a community of symbionts, it may be absent because of the shrimps' house-keeping activities. Laboratory observations demonstrate that the burrow walls are frequently tended, as in Callianassa subterranea, in order to maintain the smooth surface and circular cross section, features necessary for efficient water flow.

Ott et al. (1976) suggested that Upogebia pusilla might not be a filter feeder and that the burrow might be adapted for deposit feeding or for the gardening of micro-organisms. Subsequently, Dworschak (1987) reexamined the feeding mechanisms of $U$. pusilla and separated them into 3 categories, similar to the suspension, resuspension and deposit feeding categories described above for $U$. stellata, but considered that filter feeding was the main feeding mechanism and this is probably the case for $U$. stellata also. The prominence of chambers in burrows of $U$. stellata from laboratory microcosms perhaps suggests that there is a greater emphasis on deposit or resuspension feeding under these particular laboratory conditions. Intraspecific differences in burrow morphology may thus be used to determine the relative importance of different trophic modes.

Reduction of the diameter of burrow openings, as noted for Upogebia stellata, is recognized in many upogebiids (Dworschak 1983, Vaugelas 1990). The shrimp may be making use of the Venturi effect, as speculated for Callianassa subterranea, to maximize the efficiency of current generation or may simply prevent access by surface macrofauna such as gobies which might disrupt the burrow architecture. This also indicates that shrimp do not need to access the sediment surface and that although the source of nutrition is primarily the water column, particles are extracted within the burrow. $U$. stellata, however, engages in a variety of feeding behaviours and appears to be the most flexible of the 3 thalassinideans studied in its feeding repertoire.

\section{Classification of thalassinidean burrow morphology}

The present study indicates that, depending upon environmental conditions, Callianassa subterranea, Jaxea nocturna and Upogebia stellata may exhibit some versatility in their feeding behaviour in order to exploit the most advantageous food source at a particular time, and consequently, intraspecific burrow architecture may also exhibit some plasticity. Dworschak (1983) reviewed the interspecific differences in 
thalassinidean burrow morphologies, demonstrating high levels of variation, and subsequently some authors have produced models of thalassinidean burrow architecture in relation to the function of the burrow and the trophic mode of each species (Suchanek 1985, Vaugelas 1990, Griffis \& Suchanek 1991).

Suchanek (1985) identified 3 major feeding categories, suspension feeders, deposit feeders and seagrass harvesters, each characterized by a general type of burrow morphology. Griffis \& Suchanek (1991) reviewed data from many sources and expanded the 1985 model to include a greater diversity of burrow morphologies. Within the 3 feeding modes previously identified, 6 general types of burrow architecture were now recognized

In applying this model to data from the present study, however, it is difficult to assign categories which adequately define the complete burrow morphology and trophic modes employed for any of the species examined. The burrow morphology of any particular species does not conform to the generalized architecture of any one category but instead seems to be an amalgamation of several features from different categories. Intraspecific variation, e.g. as demonstrated by burrows of Callianassa subterranea (Witbaard \& Duineveld 1989, this study), adds to the difficulty in assigning a particular category. Griffis \& Suchanek (1991) also made a distinction between burrow types such as simple $Y$ - and multiple U-shaped burrows (the latter, technically borings, being constructed in corals as opposed to soft sediments) which, in terms of the trophic modes employed by inhabiting species, are functionally similar.

The difficulty in placing each species within the model seems largely due to the plasticity of feeding behaviour and this highlights the deficiencies of the model. Burrow morphology may be functionally adapted to enhance not one but a variety of feeding modes and consequently, burrow architecture shows features of more than one of the types described in the model. Intraspecific differences in burrow morphology may be as great as the presence or absence of prominent characteristics such as surface mounds and under varying environmental conditions, differences within the burrow structures will functionally enhance particular trophic modes. Dworschak \& Ott (1993) similarly criticised Griffis \& Suchanek's model, pointing out the difficulty in assigning certain species to a burrow type when the variety of feeding modes employed and environmental differences are considered. Griffis \& Suchanek (1991) acknowledged that there is variation in the use of feeding modes and that a single species may be capable of more than one; thus the model is perhaps too specific in assigning a trophic category.
Vaugelas (1990) proposed a classification of burrows, based on a knowledge of feeding in decapods in general and thalassinideans in particular, which addressed the problem of burrow morphologies which overlap trophic categories to a greater degree than in Griffis \& Suchanek's model (1991). Burrow morphologies were categorized with greater regard to functional rather than physical similarity and 4 trophic categories were recognized, which included deposit feeders, deposit/suspension feeders (for which the burrow is adapted to both trophic modes) and the primarily suspension feeders. The fourth category, 'drift catchers' (Griffis \& Suchanek 1991), contained the 'sea grass/algae harvesters' first erected by Suchanek (1985) but Vaugelas (1990) suggested that this term was too restrictive and that 'omnivorous scavenger' would be more appropriate to encompass the feeding mode of this group. This would allow the inclusion of species such as Jaxea nocturna (based on data from the present study) which were previously excluded from the 'drift catcher' category.

Vaugelas (1990) stated that depending on the nutritional source available, species may exhibit trophic plasticity. Although his model allowed for this, its primary deficiency was that some of the categories still did not adequately include all the morphological features seen within the burrow architecture of any particular species. Permanently open exhalant shafts, for example, are suggested to be characteristic of deposit/suspension feeding but the present study has demonstrated that this is not always the case for Callianassa subterranea. Vaugelas (1990) acknowledged, however, that there was heterogeneity in burrow architecture within the feeding categories. In taking greater account of intraspecific trophic plasticity, Vaugelas (1990) has constructed a generalistic but also perhaps more robust model than that of Griffis \& Suchanek (1991).

Due to the difficulty in obtaining data on feeding behaviour for the thalassinideans, the ultimate goal of any model must be the use of burrow structure in isolation to infer trophic modes. Rather than classifying complete burrow morphologies, individual components can perhaps be recognized which indicate that a particular feeding mode is possible and by considering the overall burrow morphology together with environmental variables, of which sedimentary organic carbon levels may be crucial, conclusions can be drawn about the relative importance of each trophic mode for that particular species in a specific habitat. Drawing on data from the present study but also from Vaugelas (1990) and Griffis \& Suchanek (1991), we suggest here an alternative approach to the trophic classification of thalassinidean burrow morphology. 
Based primarily on the burrow morphologies and feeding behaviours of Callianassa subterranea, Jaxea nocturna and Upogebia stellata, Fig. 3 details 12 burrow features which are believed to be indicative of certain trophic requirements or modes. Surface mounds (Feature 1) are caused by removal of sediment from the burrow to the surface and, apart from during burrow construction, are indicative of a deposit feeding trophic mode. The origin of this sediment, however, can be either surface, as for some tropical callianassid species using the burrow as a sediment trap (Suchanek 1983, Poore \& Suchanek 1988, Vaugelas 1990) and as speculated for C. subterranea from the North Sea (Witbaard \& Duineveld 1989), or subsurface, as for C. subterranea from the present study. In addition, mound size, which in the absence of tidal currents is reflective of the rate of sediment processing, may be related to organic carbon content of sediments (Vaugelas et al. 1986, Nickell 1992). A tightly layered lattice (Feature 2) suggests that a given volume of sediment is being maximally exploited by a subsurface deposit feeder and the deeper this lattice occurs, the less the dependence upon surface sediments. Thus, burrow depth (Feature 3) can be indicative of the relative importance of surface sediments or scavenged material in the shrimp's nutrition. Further work on the nutritional sources available at various depths would be instructive.

Sub-circular tunnels (Feature 4) tend to develop as a result of shrimp movement and will occur in established burrows, such as those of Jaxea nocturna, in which the shrimp is not continuously maintaining the burrow walls. Sub-circular burrow tunnels and shafts are less suitable for efficient current flow; thus suspension feeding is less likely and burrow permanence indicates that sub-surface deposit feeding is not of primary importance. The burrow refuge is again a feeding location but in this case the most likely origin of material (either sediment or other organic material) is the sediment surface, suggesting a deposit feeding or omnivorous scavenging trophic mode.

Chambered burrows (Feature 5) can be used for subsurface deposit feeding but may also be used to store surface or sub-surface material. In burrows of both Callianassa subterranea and Jaxea nocturna, chambers represent areas where sediment has been removed probably for deposit feeding, and in the case of the former, chambers may also be backfilled with material mined from elsewhere in the burrow. Chambers may also function for the storage of coarse material as found in the pocket-like chambers at the base of the inhalant shaft in burrows of $C$. subterranea and also in the sump which is essentially a vertically orientated chamber. This would suggest that mined sediment is being sorted and coarse particles are dumped at specific locations within the burrow, as in C. subterranea from the present study, or that surface material is falling into the burrow [cf. the sediment trap of Suchanek (1983)]. Both possibilities give evidence for deposit feeding. The presence of large pieces of organic material in the burrow (Feature 6) may be a result of scavenging on the surface, a behaviour recorded for $J$. nocturna and also Corallianassa longiventris and Axiopsis serratifrons (Suchanek 1985, Manning 1987, Dworschak \& Ott 1993), but the possibility remains that in some cases this material may enter the burrow passively and is stored in a tunnel floor or a chamber to prevent blockages. Further investigation of feeding behaviour in other thalassinidean species is necessary to shed light on the question of whether this material is consumed directly or indirectly, by using it to cultivate micro-organisms which are then consumed.

Oblique tunnels (Feature 7) allow access to the sediment surface for the movement of sediment or macroorganic material in or out of the burrow and would thus also suggest a deposit feeding or omnivorous scavenging trophic mode. Many burrow openings (Feature 8) suggest necessary contact with the sediment surface for deposit feeding or scavenging, allowing access to a wider area of sediment without straying too far from the safetly of a burrow opening. Alternatively, if the burrow is being used as a sediment trap to capture material for deposit feeding, the shrimp may not need to leave the burrow whilst numerous openings would increase the catch of surface material. The possession of funnel-shaped openings (Feature 9) would enhance capture of particles which will slip down the sides of the funnel. In addition, funnel-shaped openings are characteristic of inhalant shafts in burrows of Callianassa subterranea. These are thought to develop through the displacement of sediment around the opening due to inflow of water and the resulting subducted and suspended particles may provide a further nutritional source for deposit or suspension feeding, respectively.

The narrow exhalant shaft (Feature 10) indicates a necessity for current generation. Where a burrow has a complex structure or is very deep (such as the lattice of tunnels and chambers in burrows of Callianassa subterranea), this shaft may be a requirement for the replenishment of oxygen levels through burrow irrigation. It may also assist efficient removal of suspended waste sediment from within the burrow and thus may be indicative of a deposit feeding trophic mode. Such water currents, however, may also be used for suspension feeding. The narrow exhalant shaft is essentially a modification of the U- or Y-shaped burrow construction (Feature 11) as the inhalant and exhalant together form a basic U. Upogebia spp. seem to specialize in simple U- or Y-shaped burrow morphologies and sus- 


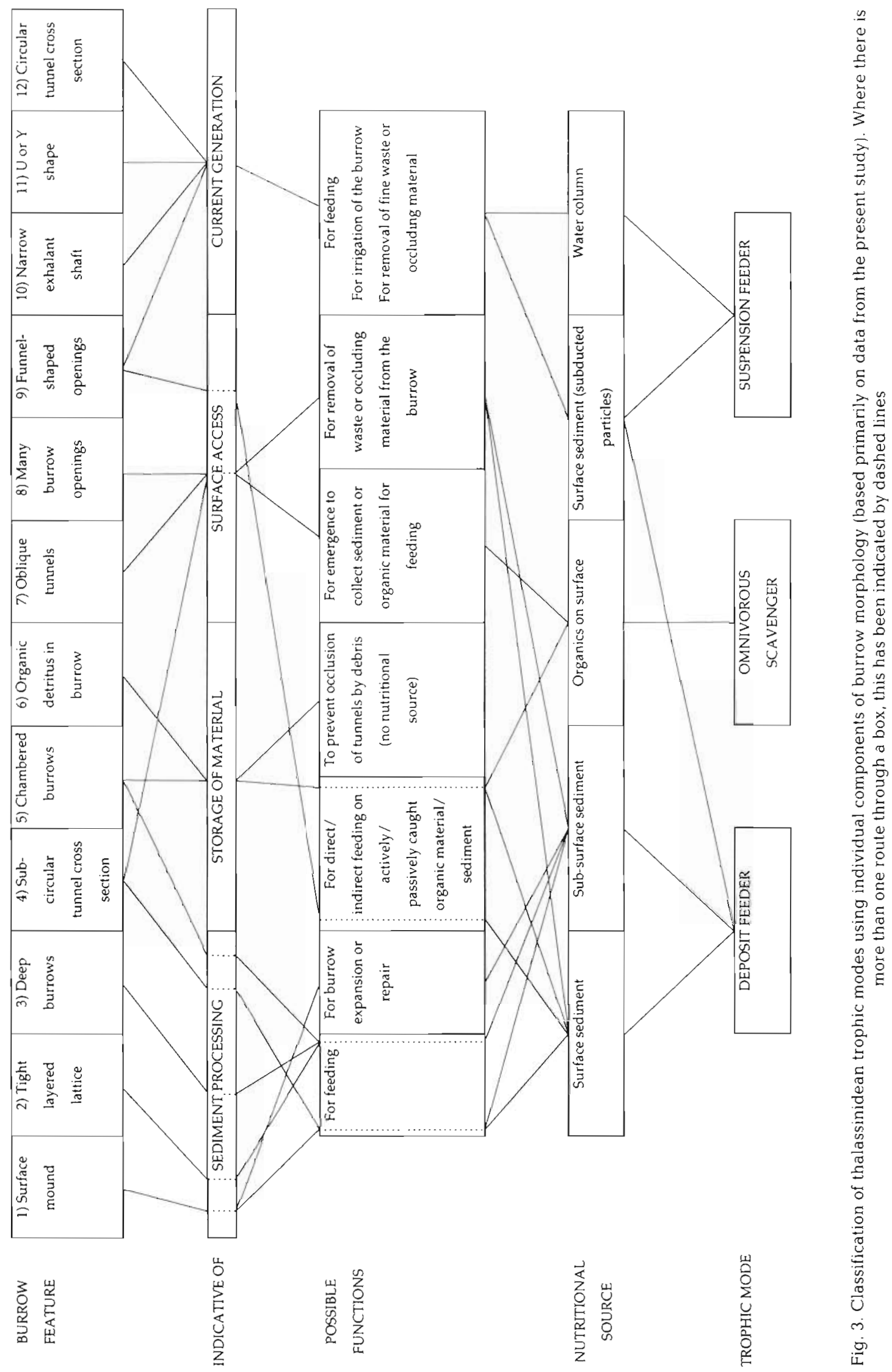


pension feeding is well recognized for this group (MacGinitie 1930, Schaefer 1970, Powell 1974, Dworschak 1987. Scott et al. 1988). Circular tunnel cross sections (Feature 12) facilitate efficient flow and also current generation by allowing a close fit between pleopod and tunnel dimensions. Careful maintenance of this feature, even in burrows of a primarily deposit feeding animal such as $C$. subterranea, suggests that efficient through-burrow water flow is important here also.

Even though a particular trophic mode is being used preferentially, the burrow may show morphological features suggestive of alternative trophic modes, possibly because of the phylogenetic component to burrow architecture upon which environmental influences are imposed (Dworschak \& Ott 1993) or because activity by the shrimp may coincidentally lead to certain other features being present, e.g. large pieces of organic material being brought into the burrow by irrigation currents or the $\mathrm{U}$-shaped surface connections necessary for irrigation in burrows of deposit feeders. The individual features of a burrow must therefore be considered together in the light of local environmental factors and, if possible, animal anatomy (which will define which trophic modes a species can utilize and impose certain structural constraints) before a judgement can be made on the most likely trophic mode or modes being employed by that particular shrimp.

It should be emphasised that the list of burrow features considered here is not complete. It is hoped that further direct observations of feeding behaviour in other thalassinidean species will continue to clarify the functional morphology of different components of burrow architecture. It will then be possible to build upon this proposed approach to trophic classification of thalassinidean burrows, adapting, modifying and adding to it as necessary, in order to strengthen our understanding of the autecology of these animals.

Acknowledgements. We thank the divers and students at UMBSM who assisted with field work, in particular $\mathrm{K}$ Cameron and I. Tuck, and also the crews of RV 'Aora' and 'Aplysia' We also thank Dr P. C. Dworschak for his constructive comments. This research was carried out as part of a Natural Environment Research Council CASE Ph.D. studentship award, between University Marine Biological Station Millport and Dunstaffnage Marine Laboratory, to L.A.N.

\section{LITERATURE CITED}

Allanson BR, Skinner D, Imberger J (1992) Flow in prawn burrows. Estuar coast mar Sci 35:253-266

Atkinson RJA (1974) Spatial distribution of Nephrops burrows. Estuar coast mar Sci 2:171-176

Atkinson RJA (1986) Mud-burrowing megafauna of the Clyde Sea area. Proc R Soc Edinb 90B:351-361
Atkinson RJA (1987) The burrowing megafaunal communities of the upper arms of Loch Sween. Report to the Nature Conservancy Council, Peterborough, from the University Marine Biological Station, Millport, p 1-65

Atkinson RJA (1989) Baseline survey of the burrowing megafauna of Loch Sween, Proposed Marine Nature Reserve, and an investigation of the effects of trawling on the benthic megafauna. Report to the Nature Conservancy Council, Peterborough, from the University Marine BioIogical Station, Millport, p 1-59

Atkinson RJA, Chapman CJ (1984) Resin casting: a technique of investigating burrows in sublittoral sediments. Prog underwat Sci 9:15-25

Atkinson RJA, Nash RDM (1990) Some preliminary observations on the burrows of Callianassa subterranea (Montagu) (Decapoda: Thalassinidea) from the west coast of Scotland. J nat Hist 24:403-413

Braithwaite CJR, Talbot MR (1972) Crustacean burrows in the Seychelles, Indian Ocean. Palaeogeogr Palaeoclimatol Palaeoecol 11:265-285

Buchanan JB (1963) The biology of Calocaris macandreae (Crustacea: Thalassinidea). J mar biol Ass UK 43:729-747

Colin PL, Suchanek TH, McMurty G (1986) Water pumping and particulate resuspension by callianassids at Enewetak and Bikini Atolls, Marshall Islands. Bull mar Sci 38:19-21

Devine CE (1966) Ecology of Callianassa filholi MilneEdwards 1878 (Crustacea, Thalassinidea). Trans R Soc NZ, Zool 8:93-110

Dworschak PC (1983) The biology of Upogebia pusilla (Petagna) (Decapoda, Thalassinidea). I. The burrows Mar Ecol 4:19-43

Dworschak PC (1987) Feeding behaviour of Upogebia pusilla and Callianassa tyrrhena. Investigación pesq 51:421-429

Dworschak PC, Ott JA (1993) Decapod burrows in mangrovechannel and back-reef environments at the Atlantic Barrier Reef, Belize Ichnos 2:277-290

Dworschak PC, Pervesler P (1988) Burrows of Callianassa bouvieri Nobili 1904 from Safagu (Egypt, Red Sea) with some remarks on the biology of the species. Senckenberg marit 20:1-17

Farrow GE (1971) Back-reef and lagoonal environments of Aldabra Atoll distinguished by their crustacean burrows. Symp Zool Soc Lond 28:455-500

Frey RW, Howard JD (1975) Endobenthic adaptations of juvenile thalassinidean shrimp. Bull Geol Soc Denmark 24: $283-297$

Frey RW, Howard JD, Pryor WA (1978) Ophiomorpha: its morphologic, taxonomic and environmental significance. Palaeogeogr Palaeoclimatol Palaeoecol 23:199-229

Griffis RB, Chavez FL (1988) Effects of sediment type on burrows of Callianassa californiensis Dana and C gigas Dana. J exp mar Biol Ecol 117:239-253

Griffis RB, Suchanek TK (1991) A model of burrow architecture and trophic modes in thalassinidean shrimps (Decapoda: Thalassinidea). Mar Ecol Prog Ser 79:171-183

Hughes DJ, Ansell AD, Atkinson RJA, Nickell LA (1993) Underwater television observations of surface activity of the echiuran worm Maxmuellena lankesteri (Echiura: Bonellidae). J nat Hist 27:219-248

MacGinitie GE (1930) The natural history of the mud shrimp Upogebia pugettensis Dana. Ann Mag nat Hist Ser 10, 6:36-47

MacGinitie GE (1934) The natural history of Callianassa callforniensis Dana. Am Midl Nat 15:166-177

Manning RB (1975) Two methods for collecting decapods in shallow water. Crustaceana 29:317-319

Manning RB (1987) Notes on western Atlantic Callianassidae 
(Crustacea: Decapoda: Thalassinidea). Proc Biol Soc Wash 100:386-401

Manning RB, Felder DL (1991) Revision of the American Callianassidae (Crustacea: Decapoda: Thalassinidea). Proc Biol Soc Wash 104:764-792

Nardo GD (1847) Sinonimia moderna delle specie registrate nell'opera intitolata: descrizione de crostacei, de testacei e de pesci che abitano le lagune e golfo Veneto rappresetati in figure, a chiaro-scuro dall'abate Stefano Chiereghini Ven. Clodiense applicata per commissione governativa, Venezia, p 1-127

Nash RDM, Chapman CJ, Atkinson RJA, Morgan PJ (1984) Observations on the burrows and burrowing behaviour of Calocaris macandreae (Crustacea: Decapoda: Thalassinidea). J Zool, Lond 202:425-439

Nickell LA (1992) Deep bioturbation in organically enriched marine sediments. PhD thesis, University of London, p $1-400$

Nickell LA, Atkinson RJA, Hughes DJ, Ansell AD, Smith CJ (1995). Burrow morphology of the echiuran worm Maxmuelleria lankesteri (Echiura: Bonellidae) and a brief review of burrow structure and related ecology of the Echiura. J nat Hist 29:871-885

Ott JA, Fuchs B, Fuchs R, Malasek A (1976) Observations on the biology of Callianassa stebbingi Borradaille and Upogebia litoralis Risso and their effect on the sediment. Senckenberg marit 8:61-79

Pearse AS (1945) Ecology of Upogebia affinis (Say). Ecology 26:303-305

Pemberton GS, Risk MJ, Buckley DE (1976) Supershrimp: deep bioturbation in the Strait of Canso, Nova Scotia. Science 192:790-791

Pervesler P, Dworschak PC (1985) Burrows of Jaxea nocturna Nardo in the Gulf of Trieste. Senckenberg marit 17:33-53

Pesta O (1918) Die Decapodenfauna der Adria. Versuch einer Monographie. Franz Deuticke, Leipzig, p 1-500

Pohl ME (1946) Ecological observations on Callianassa major Say at Beaufort, North Carolina. Ecology 27:71-80

Poore GCB, Suchanek TH (1988) Glypturus motupore, a new callianassid shrimp (Crustacea: Decapoda) from Papua New Guinea with notes on its ecology. Proc Aust Mus 40: 197-204

Powell RR (1974) The functional morphology of the fore-guts of the thalassinid crustaceans, Callianassa californiensis and Upogebia pugettensis. Univ Calif Publs Zool 104:1-41

Rice AL, Chapman CJ (1971) Observations on the burrows and burrowing behaviour of the mud-dwelling crustaceans, Nephrops norvegicus and Goneplax rhomboides. Mar Biol 10:330-342

Rodrigues SA (1983) Aspectos da biologia de Thalassinidea do Atlantico tropical americano. Publicações do Instituto de Biociencias da Universidade de São Paulo, p 1-174

Rodrigues SA, Hodl W (1990) Burrowing behaviour of Callichirus major and C. mirim. Begleitveröffentlichung zum wissenschaftlichen Film C2199 des ÖWF. Wissenschaftlicher Film (Wien) 41:48-58

Schaefer N (1970) The functional morphology of the foregut of three decapod Crustacea: Cyclograpsus punctatus

This article was presented by D. S. McLusky (Senior Editorial Advisorl, Stirling, UK
Milne-Edwards, Diogenes brevirostris Stimpson and Upogebia africana (Ortmann). Zool Afr 5:309-326

Scott PJB, Reiswig HM, Marcotte BM (1988) Ecology, functional morphology, behaviour and feeding in coral- and sponge-boring species of Upogebia (Crustacea: Decapoda: Thalassinidea). Can J Zool 66:483-495

Shinn EA (1968) Burrowing in recent lime sediments of Florida and the Bahamas. J Paleontol 42:879-894

Suchanek TH (1983) Control of seagrass communities and sediment distribution by Callianassa (Crustacea, Thalassinidea) bioturbation. J mar Res 41:281-298

Suchanek TH (1985) Thalassinid shrimp burrows: ecological significance of species-specific ârchitecture. In: Delesalle B (ed) Proceedings of the 5th International Coral Reef Congress, Tahiti, 27 May-1 June 1985, Vol 5. Antenne Museum, Ephe, Moorea, French Polynesia, p 205-210

Suchanek TH, Colin PL, McMurty GM, Suchanek CS (1986) Bioturbation and redistribution of sediment radionuclides in Enewetak Atoll lagoons by callianassid shrimps: biological aspects. Bull mar Sci 38:144-154

Swinbanks DD, Murray JW (1981) Biosedimentological sedimentation of Boundary Bay tidal flats, Fraser River delta, British Columbia. Sedimentology 28:201-237

Thompson RK, Pritchard AW (1969) Respiratory adaptations of two burrowing crustaceans, Callianassa californiensis and Upogebia pugettensis (Decapoda, Thalassinidea). Biol Bull 136:274-287

Tudhope AW, Scoffin TP (1984) The effects of Callianassa bioturbation on the preservation of carbonate grains in Davies Reef Lagoon, Great Barrier Reef, Australia. J sedim Petrol 54:1091-1096

Vaugelas JV de (1984) Preliminary observations on two types of callianassids (Crustacea; Thalassinidea) burrows, Gulf of Aqaba (Red Sea). Proc First Int Symp Coral Reef Environ Red Sea 1:520-539

Vaugelas JV de (1985) Sediment reworking by callianassid mud-shrimps in tropical lagoons: a review with perspectives. Proc Fifth Int Symp Coral Reef Environ Red Sea 5: $617-622$

Vaugelas JV de (1990) Ecologie des callianasses (Crustacea, Decapoda, Thalassinidea) et milieu récifal Indo-Pacifique. Conséquences du remaniement sédimentaire sur la distribution des matieres humiques, des métaux trace et des radionucléides. Memoire présenté a l'Universisté de Nice, p $1-269$

Vaugelas JV de, Delesalle B, Monier C (1986) Aspects of the biology of Callichirus armatus (A. Milne Edwards, 1870) (Decapoda, Thalassinidea) from French Polynesia. Crustaceana 50:204-216

Witbaard R (1991) Measurements on burrows of Callianassa subterranea made in a mesocosm. In: Duyl FC van (ed) The applicability of mesocosms in North Sea eutrophication studies. Nederlands Instituut voor Onderzoek der Zee, Rapport 5, Texel, p 101-107

Witbaard R, Duineveld GCA (1989) Some aspects of the biology and ecology of the burrowing shrimp Callianassa subterranea (Montagu) (Thalassinidea) from the southern North Sea. Sarsia 74:209-219

Manuscript first received: April 3, 1995

Revised version accepted: July 6, 1995 